\title{
How Well Are Your Police Doing?: The Relationship Between Fear of Crime and Perceptions of the Police
}

\author{
Erin Bixler
}

Follow this and additional works at: https://researchrepository.wvu.edu/etd

\section{Recommended Citation}

Bixler, Erin, "How Well Are Your Police Doing?: The Relationship Between Fear of Crime and Perceptions of the Police" (2015). Graduate Theses, Dissertations, and Problem Reports. 5217.

https://researchrepository.wvu.edu/etd/5217

This Thesis is protected by copyright and/or related rights. It has been brought to you by the The Research Repository @ WVU with permission from the rights-holder(s). You are free to use this Thesis in any way that is permitted by the copyright and related rights legislation that applies to your use. For other uses you must obtain permission from the rights-holder(s) directly, unless additional rights are indicated by a Creative Commons license in the record and/ or on the work itself. This Thesis has been accepted for inclusion in WVU Graduate Theses, Dissertations, and Problem Reports collection by an authorized administrator of The Research Repository @ WVU. For more information, please contact researchrepository@mail.wvu.edu. 
How Well Are Your Police Doing?: The Relationship Between Fear of Crime and Perceptions of the Police

\section{Erin Bixler}

Thesis submitted

to the Eberly College of Arts and Sciences at West Virginia University

in partial fulfillment of the requirements for the degree of

Master of Arts in

Sociology

Rachel Stein, Ph.D., Chair

Jesse Wozniak, Ph.D.

Amy Hirshman, Ph.D.

Department of Sociology and Anthropology

Morgantown, West Virginia

2015

Keywords: fear of crime, perceptions, policing, disorder, vulnerability

Copyright 2015 Erin Bixler 


\section{Abstract \\ How Well Are Your Police Doing?: The Relationship Between Fear of Crime and Perceptions of the Police}

\section{Erin Bixler}

Research on the fear of crime, or the fear of victimization, started becoming a popular topic in the late 1960s and has stayed in the spotlight since then. However, there has been a very small amount of literature that has focused on how an individual's fear of crime impacts their perceptions of the police. There has also been cloudiness in previous literature about how to measure fear of crime. This study examines the relationship between an individual's fear of crime and their perceptions of the police using two different measures of police, perceptions of police effectiveness and perceptions of community policing. Additionally, this study compared two different measurements of fear of crime, a general measure and a specific measure, to determine which is a better predictor of perceptions of police. The data for this study are obtained from the 2008-2009 survey Developing Uniform Performance Measures for Policing in the United States: A Pilot Project in Four Agencies. Results showed that the better predictor of perceptions of police depended on which aspect of police is being measured. Additionally, results showed that as an individual's fear of crime increases, their perceptions of the police become more negative. The results of this study will be useful to police departments, government agencies and communities around the country. 


\section{Table of Contents}

CHAPTER 1 - INTRODUCTION ............................................... 1

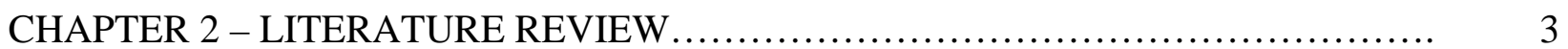

$2.1 \quad$ Perceptions of Police................................................ 3

2.2 Fear of Crime and Its Impact on Perceptions of Police................... 4

$2.3 \quad$ Fear of Crime .............................................................. 8

$2.4 \quad$ Perceptions of Vulnerability................................................. 9

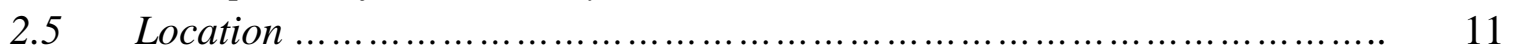

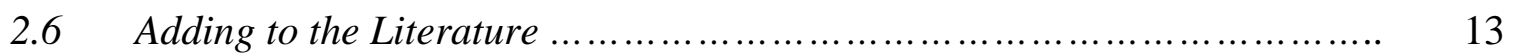

CHAPTER 3 - RESEARCH MODEL AND HYPOTHESES .............................. 13

CHAPTER 4 - DATA ........................................................ 14

CHAPTER 5 -VARIABLES.................................................. 15

CHAPTER 6 - SAMPLE DESCRIPTION ........................................ 18

CHAPTER 7 - STATISTICAL ANALYSIS...................................... 19

7.1 Descriptive statistics of respondent characteristics ......................... 20

$7.2 \quad$ Correlation matrixes ........................................................ 22

$7.3 \quad$ Logistic Regressions ................................................ 27

CHAPTER 8 - DISCUSSION AND CONCLUSIONS................................ 32

8.1 Limitations and Future Research.................................. 37

REFERENCES CITED.......................................................... 40 


\section{Introduction}

Fear of crime impacts every aspect of an individual's life, from how they interact with other individuals, to where they choose to live and work. If an individual does not feel safe in their community they are going to tell others and discourage potentially beneficial individuals from moving or working in certain neighborhoods. If individuals do not feel safe they are less likely to be willing to work with the police, resulting in potentially more crime. Additionally, if individuals do not support their police, the police department might suffer budget or manpower cuts that would in turn affect the community. This research expands on the importance of studying fear of crime and its impact on an individual's perception of the police. This research also examines which type measurement of fear of crime is a better predictor of perceptions of police. Perceptions of the police are measured as how effective an individual perceives the police to be and how involved in the community an individual perceives his/her police to be. Fear of crime is defined as when an individual worries about their personal safety, victimization, or the safety of their loved ones (Wyant 2008). The results of this study are important to everyone, due to the impact that fear of crime has on every aspect of society, but it is especially important to police departments and government agencies.

Research on the fear of crime or the fear of victimization, became a popular topic in the late 1960s and has stayed in the spotlight since then (Ferraro and LaGrange 1987; Scarborough, Haislip, Novak, Lucas, and Alarid 2010; Schafer, Huebner, and Bynum 2006; Warr and Stafford 1983; Wyant 2008; Zhao, Lawton, and Longmire 2015). Previous research has looked at perceptions of police and how to examine the relationship between fear of crime and perceptions of the police (Benedict, Brown and Bower 2000; Kort-Butler and Sittner-Hartshorn 2011; Schafer, Huebner, and Bynum 2003; Skogan 2009; Thomas and Hyman 1977; Weitzer and Tuch 
2005). Previous research has also examined how individual characteristics and how disorder in an individual's environment all shape an individual's fear of crime and their perceptions of the police (Ferraro and LaGrange 1992; LaGrange, Ferraro, and Supancic 1992; Rader, Cossman, and Porter 2012; Sampson and Raudenbush 2004; Scarborough et al. 2010; Schafer et al. 2006; Skogan 1986; Wilson and Kelling 1982; Wyant 2008).

Perceptions of the police are very important to study because the police impact so many individuals in both direct and indirect ways (Schafer et al. 2003; Thomas and Hyman 1977). As Schafer et al. (2003) state "the effectiveness of a public service organization is linked to its ability to provide quality services while maintaining a positive public image” (p.440). Meaning, police effectiveness is not enough; police also have to maintain a positive image while being effective to make the community happy. Previous research finds that the American public has a positive attitude towards the police (Benedict et al. 2000; Schafer et al. 2003; Thomas and Hyman 1977). However, whether or not individuals have any interaction with the police can impact their attitudes towards the police (Schafer et al. 2003).

Researchers find that direct interactions with the police have more of an impact on an individual's perceptions than any other variable (Schafer et al. 2003). Previous research also shows that it does not matter how often an individual interacts with the police, what matters is what kind of experience an individual has when interacting with the police. If an individual has a negative interaction with the police, even if it is only once, they are more likely to have negative perceptions of the police (Schafer et al. 2003). The same is not true for positive interactions with the police. If an individual has a positive interaction with the police, there is no evidence that they are going to have positive perceptions of the police (Schafer et al. 2003). Although direct interactions with the police are extremely important, the number of individuals 
that actually have that experience is very limited. Based on the fact that the number of direct interactions is so limited, it is extremely important to examine an individual's perceptions of the police and to see how and what effects those perceptions.

This study adds to previous literature by adding research on the relationship between an individual's fear of crime and their perceptions of the police. To do this, fear of crime is operationalized in two ways. First, the general fear of crime measure that has been used for years and second, a new type of measurement which looks at fear of specific crimes. By doing this, the research determines which is better predictor of perceptions of police and expands on the conflicting findings of previous research. This study also expands on the previous research on what goes into forming an individual's fear of crime. Finally, this research adds to the literature using two different variables to measure perceptions of the police, police effectiveness and community policing. This study examines how an individual's fear of crime, using both a general measure and specific measures, affect their perceptions of the police.

\section{Literature Review}

\section{Perceptions of Police}

While interactions with the police have a lasting impact on an individual's perceptions, most individuals do not actually have any direct interactions with the police. Due to the lack of interaction most individuals in society have with the police, it is important to examine studies such as the Kansas City Preventative Patrol Experiment, conducted by George Kelling. This experiment is one of the most influential and widely cited policing experiments aimed to determine whether or not increased police patrol decreased criminal activity and increased residents feeling of safety (Ratcliffe, Taniguchi, Groff, and Wood 2011; Stewart 1990). The 
experiment found that increased preventive patrol did not have an impact on an individual's fear of crime or feeling of security (Kelling, Pate, Dieckman, and Brown 1974).

Since a majority of residents did not have any direct interaction with the police, they were still basing their fear of crime off perceptions. Schafer et al. (2003) found the same concept; even in better policed areas perceptions of fear are what have a major impact on fear of crime. Another example of the impact perceptions can have is when examining crime rates. Unless an individual is involved with some aspect of the criminal justice system, they are likely to not know accurate crime rates (Glassner 2009). In today's society, many individuals view crime rates as increasing; however, crime rates are actually decreasing (Glassner 2009). Again, this supports the statement that opinions or perceptions are so influential and important because perceptions are the only thing a majority of individuals have to rely on when forming opinions about crime and the police.

\section{Fear of Crime and Its Impact on Perceptions of Police}

The criminal justice field is highly impacted by an individual's fear of crime, especially for the police. There are a small number of studies that actually examine the relationship between an individual's fear of crime and their perceptions of the police, but they provide conflicting results (Benedict et al. 2000; Kort-Butler and Sittner-Hartshorn 2011; Skogan 2009; Weitzer and Tuch 2005). Weitzer and Tuch (2005) and Kort-Butler and Sittner Hartshorn (2011) found that perceptions of the police are significantly impacted by an individual's fear of crime. Although, Kort-Butler and Sittner-Hartshorn (2011) and Weitzer and Tuch (2005) found the same end results, their measurements of fear of crime and perceptions of police are different.

In the article by Weitzer and Tuch (2005), participants were asked about their fear of crime and their satisfaction with police. All individuals in this survey were part of the 
Knowledge Networks, a web-based survey research firm. There were seven total hypotheses that Weitzer and Tuch were interested in testing; two of the hypotheses focused on an individual's fear of crime and their satisfaction with the police. Satisfaction with the police was measured with two questions: (1) "In general, how satisfied or dissatisfied are you with the police department in your city?” and (2) “In general, how satisfied or dissatisfied are you with the police officer who serve your neighborhood?” In order to measure an individual's fear of crime, individuals were asked the question that many criminologists have used for years, "Overall, how safe do you feel being alone outside in your neighborhood both during the night and during the day?” Respondents were also asked about fear of crime with the question "How serious a problem is crime in your neighborhood?” Based on these measurements Weitzer and Tuch (2005) found that as an individual's fear of crime increases, their satisfaction of the police decrease.

Although Weitzer and Tuch (2005) found a statistically significant relationship between the two variables, fear of crime and perceptions of the police, many researchers argue there is a better way to measure fear of crime and perceptions of police. The first measure of fear that was used "how safe do you feel being alone outside in your neighborhood both during the night and day?” is a question that has been used since the 1980s and has come under much criticism (Baumer 1985). In order to obtain a more accurate representation of an individual's fear of crime, questions about fear of specific types of crime need to be asked.

Kort-Butler and Sittner Hartshorn (2011) and Skogan (2009) examined fear of specific crimes on perceptions of police, rather than using the general fear of crime variable. Kort-Butler and Sittner Hartshorn (2011) collected their sample from individuals residing in the state of Nebraska who were 19 years or older and had access to a home telephone during February 2008 
and August 2008. Individuals in Kort-Butler and Sittner Hartshorn’s (2011) study were asked six questions about their fear of crime. These questions included: worry about walking alone at night, getting robbed, having their residence broken into, being sexually assaulted, getting murdered, and having someone in their family be a victim of a crime. These six questions were then averaged into an overall indicator of fear.

Kort-Butler and Sittner Hartshorn (2011) used a variety of questions to measure their dependent variable but they did not focus specifically on police. Three of the questions asked about their confidence in police protecting individuals from crime and three were about how fair the criminal justice system is. These six questions were then turned into a "support for the criminal justice system” index. Since three of the questions were about the criminal justice system in general, what these researchers could be measuring is perceptions of the criminal justice system overall (i.e. courts, prisons, etc.) instead of just perceptions of the police. However, even with the differences in measurements, Kort-Butler and Sittner Hartshorn (2011) found that as an individual's fear of crime increases, their perceptions of the police becomes more negative.

Skogan (2009) used a similar approach to Kort-Butler and Sittner Harshron (2011) to measure fear of crime. Individuals were asked how worried they were about certain situations happening to them in their current neighborhood. They were given four different scenarios that ranged from personal to property crimes. Skogan (2009) measured perceptions of the police which he called "confidence in the police.” In order to measure confidence in police, respondents were asked multiple questions such as, "How good a job do you think police in this area are doing with respect to preventing crime, helping people out after they have been victims of a crime, and keeping order on the streets and sidewalks?” Individuals were also asked about 
confidence in the way police handled themselves with the question "in general, how polite are the police in this area when dealing with people?”

Contradictory to the previously mentioned researchers, Skogan (2009) reported that there is not enough evidence between an individual's fear of crime and their confidence in the police for the results to be statistically significant. The contradictory findings could be because of the way the variables were operationalized in the study. Skogan (2009) ultimately asked about confidence in the police, he did not ask about police effectiveness or community policing. Also, Skogan (2009) sampled four neighborhoods around Houston, Texas that were picked specifically because they were racially diverse, faced significant crime problems, and were demographically similar. Although Skogan (2009) did not find his results to be statistically significant, his data suggest that when individuals have a higher fear of crime, they are more likely to distrust the police and there is more likely to be more hatred towards the police.

Both Kort-Butler and Sittner-Hartshorn (2011) and Skogan (2009) expanded on the general fear of crime variable to gather a more accurate picture of an individual's fear of crime and how it impacts perceptions of police. However, both studies failed to measure perceptions of police in as much detail, leaving room for discussion on how to properly measure the variable. Additionally, they both measured perceptions of police in two different ways.

Even with all of the previous research that has been conducted on fear of crime, researchers still argue about the proper way to actually measure fear of crime (Zhao et al. 2015). According to Ferraro and LaGrange (1987) the measurement of fear of crime is incredibly “cloudy” and many authors measure it in many different ways. Since there are different variations of an individual's fear of crime and since fear of crime tends to alter individuals 
activity in their everyday lives, and how they view the police, it is very important to continue research on the topic (Chadee and Ng Ying 2013; LaGrange et al. 1992; Zhao et al. 2015).

\section{Fear of Crime}

As research on perceptions is difficult, investigators have begun to change the way they measure fear of crime. The first and most widely used measure for fear of crime was introduced in the 1980s by the National Crime Survey and asked "how safe do you feeling walking alone at night” (Baumer 1985). For the next decade, this was the question used when researchers were interested in measuring fear of crime. In the early 1990s, researchers started to introduce new questions such as "how safe do you feel walking alone during the day” (Covington and Taylor

1991). However, researchers argue that these two questions do not actually measure how fearful an individual is. Fear of crime is ultimately a fear of being victimized (Wyant 2008). Simply asking an individual how safe they feel walking alone at night and during the day could be missing how worried they are about actually becoming a victim. Also, every respondent could interpret the question very differently meaning results could vary.

Since 2000, researchers such as Kort-Butler and Sittner Hartshorn (2011) and Skogan (2009) introduced a new measurement where the focus is on specific types of victimization. They measure these specific types of fear of crime by simply asking, "How worried are you of being a victim of this specific type of crime.” This new measurement is less likely to be interpreted in different manners then the general fear variable of walking alone at night. By asking this type of direct question, researchers are specifically asking how worried an individual is of being a victim of a specific type of crime. By asking about fear of specific crimes, researchers can form an index to form an overall fear of crime variable or they can focus on how fear of specific crimes affects different aspects of the criminal just system. This new 
measurement more exactly assesses what researchers want to know: what an individual's fear of crime is and just how vulnerable an individual feels.

\section{Perceptions of Vulnerability}

The vulnerability perspective is "based on the assumption that fear was greatest when individuals perceived that they were at a physical disadvantage against potential assaults and/or when individuals believed that they were particularly vulnerable to being victims of a crime” (Wyant 2008:42). Rader et al. (2012) takes the vulnerability perspective one step further and examines physical vulnerability versus social vulnerability.

Physical vulnerability includes an individual's physical characteristics, such as their sex, or age which could make them more or less vulnerable (Rader et al. 2012). For example, as an individual's age increases their fear of crime goes up, indicating that older individuals are more fearful than younger individuals (Rader et al. 2012; Scarborough et al. 2010; Schafer et al. 2006). Older individuals are more likely than younger individuals to feel like they cannot physically defend themselves, indicating that they perceive their risk of victimization as higher than younger individuals.

Another example of physical vulnerability is an individual's sex. Research shows that women have a higher overall fear of crime than men do (Rader et al. 2012; Scarborough et al. 2010; Schafer et al. 2006). However, previous research shows that women are actually less likely to be a victim of every type of crime, except for sexual assaults (Scarborough et al. 2010). Women tend to fear sexual assault because they do not feel they are physically able to fight off an unwanted attacker, which they fear makes them an easy target (Rader et al. 2012; Schafer et al. 2006). The capability of a woman to defend herself or the actual likelihood of a woman being sexually assaulted does not matter. What matters is how a woman perceives herself; 
therefore, what matters are her perceptions. Not only does physical vulnerability have an influence on an individual's fear of crime but additionally social vulnerability has an equally important influence (Rader et al. 2012; Schafer et al. 2006).

Social vulnerability includes social characteristics, such as race and education, which makes an individual more or less vulnerable to victimization (Rader et al., 2012). Earlier studies show that blacks have a higher fear of crime than whites (LaGrange et al. 1992; Rader et al. 2012; Scarborough et al. 2010). Black individuals tend to perceive their risk of being victimized as higher than white individuals (LaGrange et al. 1992; Rader et al. 2012; Scarborough et al. 2010). This could be for a number of reasons, from the neighborhood they live in to how the family is socialized in their upbringing. Findings also show that as an individual's level of education increases, their fear of crime decreases (Scarborough et al. 2010; Schafer et al. 2006). Individuals with more education tend to make more money, meaning they live in middle class or higher neighborhoods where they perceive crime to occur less often (Schafer et al. 2006). The vulnerability perspective is overall focused on an individual's perceptions, regardless how physically fit an individual is or their social status; what they think of themselves is what matters (Ferraro and LaGrange 1992; Wyant 2008).

Research additionally finds that previous victimization has an influence on an individual's fear of crime (Rader et al. 2012; Scarborough et al. 2010; Schafer et al. 2006; Zhao et al. 2015). LaGrange et al. (1992) finds that if an individual was previously a victim they are more likely to fear that they are going to be a victim again, which would indicate a higher fear of crime.

Sampson and Raudenbush (2004) argued individual characteristics should be taken into consideration when examining perceptions of disorder in the neighborhood. In fact, when taking 
individual characteristics into consideration, $73 \%$ of the variations between the differences in perceptions of disorder are accounted for (Sampson and Raudenbush 2004). Residents of the same neighborhood will more than likely share similar characteristics or backgrounds with one another that will influence their judgments, making location equally import to individual characteristics when examining fear of crime (Wyant 2008). However, individuals in the same neighborhood are not exactly the same, indicating differences in opinions and individual characteristics. Finally, neighbors tend to feed off one another because they will share information and previous experience with each other, helping to shape opinions on fear of crime (Wyant 2008; Zhao et al. 2015).

\section{Location}

Location is a geographical area that shares similarities, whether it is the same zip code, police department, neighborhood, etc. If the location an individual lives in appears to have disorder or is not taken care of, individuals are likely to have a higher fear of crime (Sampson and Raudenbush 1999, 2004; Wilson and Kelling 1982). The disorder model examines the relationship between disorder and an individual's fear of crime, which is broken down into social disorder and physical disorder.

Social disorder refers to "behavior usually involving strangers and considered threatening, such as verbal harassment on the street, open solicitation for prostitution, public intoxication, and rowdy groups of young males in public" (Sampson and Raudenbush, 1999, p.603). Physical disorder refers to "the deterioration of urban landscapes, for example, graffiti on buildings, abandoned cars, broken windows, and garbage in the streets (Sampson and Raudenbush, 1999, p.604). Sampson and Raudenbush (2004) additionally find that many 
individuals included alcoholic beverage or tobacco advertisement and building security as signs of physical disorder.

If an individual perceives disorder in the neighborhood to be high, they are more likely to report a higher fear of crime, which in turn tends to make them keep to themselves and stay in their homes, and limits their interactions with neighbors (Wilson and Kelling 1982; Zhao et al. 2015). By individuals not interacting with one another residents and outsiders perceive the community to be uncontrolled or an easy target for crime to occur (Wilson and Kelling 1982). LaGrange et al. (1992) agrees that community disorder has been related to fear of crime for a long time and those perceptions have not changed; as disorder in the neighborhood increases, fear of crime increases.

Disorder, which can also be interpreted as a dramatic or unexpected change in society, causes an individual's fear of crime to increase. Skogan (1986) finds that individuals in a "stable" neighborhood are going to have a lower fear of crime than individuals in an "unstable" neighborhood. As he clarifies, stable does not mean that the neighborhood always stays the same. Rather by stable he means that the neighborhood goes through the same cycles consistently (Skogan 1986). When neighborhoods decline or changes are too severe, then a neighborhood becomes unstable (Skogan 1986). For example, if people in a neighborhood are used to crime occurring, even if the crime rate is high, the neighborhood would be considered stable. The constant crime would make the residents desensitized to crime and they would report a lower fear of crime. This all indicates that location is an important element when examining fear of crime.

While much of the research is focused on neighborhoods, it is important to look at how cities impact fear of crime and perceptions of police because residents in entire cities will share 
similarities (Baumer 1985; Zhao et al. 2015). Cities are also important to examine because they tend to have the same police departments between neighborhoods or if there are different police departments in the same city they tend to have the same policies and procedures impacting an individual's fear of crime (Zhao et al. 2015)

\section{Adding to the Literature}

Research on fear and perceptions of police can be a fuzzy and complicated concept. In fact, what goes into shaping an individual's fear of crime and their perceptions of the police is still far from complete (Benedict, Brown and Bower 2000; Schafer et al. 2003). The biggest gap the current research fills is looking at the importance of perceptions of policing and what best measures those perceptions. In addition, this research will add by the comparison between a specific fear of crime measure and a general fear of crime measure. Only a limited amount of researchers have focused on using fear of specific crimes as a measure. As a result of using a more specific fear of crime measurement a more accurate picture will be formed. The current research adds to the literature by examining the relationship between individuals' fear of crime and two different measures of perceptions of the police: police effectiveness and community policing. By using a new and different independent variable, examining a dependent variable that is overlooked in previous literature, and studying a relationship that is lacking current research, this study fills many gaps and adds to the literature.

\section{Research Model}

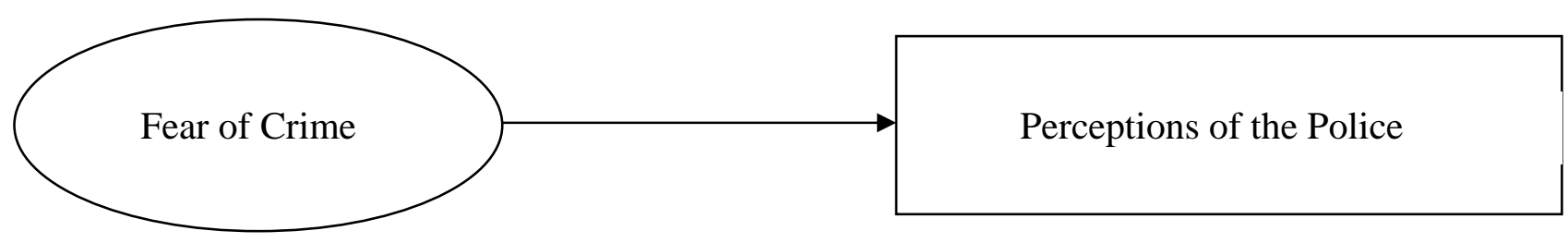




\section{Hypotheses}

$\mathrm{H}_{1}$ : The specific fear of crime measure will be a better predictor than the general fear of crime measure, when examining perceptions of police effectiveness.

$\mathrm{H}_{2}$ : The specific fear of crime measure will be a better predictor than the general fear of crime measure, when examining perceptions of community policing.

$\mathrm{H}_{3}$ : As an individual's fear of crime increases, their perceptions of the police will become more negative.

\section{Data}

The data for this research are from the 2008-2009 survey Developing Uniform Performance Measures for Policing in the United States: A Pilot Project in Four Agencies made available through the Inter-University Consortium for Political and Social Science Research (ICPSR), the primary investigator is Robert C. Davis at the RAND Co. This was a four part survey that was only collected once in the years 2008 and 2009 and was funded by the United States Department of Justice, the Office of Justice Programs, and the National Institute of Justice. The four parts of the survey included a community survey, officer survey, voluntary contact survey, and an involuntary contact survey. For the purposes of this research project, only the community survey will be used, since it was the survey that contained community members’ perceptions of police. Telephone surveys with randomly selected residents from the three counties were contacted and asked brief questions on opinions of police effectiveness and professionalism. All individuals living within the jurisdiction of Knoxville, Tennessee and Kettering, Ohio police departments and the Broward County, Florida Sheriff's Office with telephone access in between August 12, 2008 and October 7, 2008 were possible to contact for the community survey, all respondents were 18 or older and ages ranged from 18 to 96 . The 
three locations used were chosen in order to represent a small police department, a medium sized police department, and finally to represent a large sheriff's department to see how sizes of the departments varied and were similar. Calls were made by the Schaeffer Center for Public Policy at the University of Baltimore and were completed through the Schaeffer Center's CATI system. The surveys also asked individuals about neighborhood crime, disorder problems and victimization. The community survey has an N size of 319 respondents, 108 from Knoxville, 107 from Kettering, and 104 from Broward County.

\section{Variables}

\section{Dependent Variables}

There are two dependent variables used to examine perceptions of police. The first dependent variable is perceptions of police effectiveness. This is a dichotomous variable and is operationalized using the following question from the community survey: "Police effectiveness in dealing with problems that concern people in your neighborhood?” Respondents could choose $0=$ non-effective, $1=$ effective. The second dependent variable is police and community member interaction. This is a dichotomous variable and is operationalized using the following question from the community survey: "When working together with residents, police in your neighborhood do?” Respondents could choose $0=$ a bad job or $1=$ a good job.

\section{Independent Variables}

The first independent variable measure is general fear of crime. As found in previous research, there is no consistent way for researchers to measure fear of crime (Ferraro and LaGrange 1987; Scarborough et al. 2010). Therefore, the question being used to measure general fear of crime was the standard when fear of crime was first being measured. The first place the following question was used was in the 1980s and it was found in the National Crime 
Survey (Baumer 1985). The general fear of crime measure is an ordinal level variable and is operationalized using the following question from the community survey: "In your neighborhood, how much do you worry about being out at night?” $0=$ not at all worried, $1=$ somewhat worried, and 2= very worried.

To further examine the relationship between an individual's fear of crime and their perceptions of police, additional questions are used to examine more specific crimes and how they affect an individual's perceptions of police. The additional independent variables are ordinal level variables and are operationalized using the following questions from the community survey. "In your neighborhood, how much do you worry about having the following happen: 1) your car being broken into or stolen, 2) your home being broken into or stolen, 3) being assaulted or robbed, 4) people selling and using drugs, and 5) being hassled by youths or others?” Since there are numerous questions being asked, an index was created by giving each response a numerical score: $1=$ not at all worried, $2=$ somewhat worried, and $3=$ very worried. The five different questions asked were added together to create the index. The scores ranged from five to 15 , with a five representing an individual not at all worried about crime and a 15 representing an individual very worried about crime. Specifically, regarding the range of the index in this research, the scores ranged from five to 15 with a mean of eight and a mode of five. Cronbach's Alpha was run to assure reliability (Alpha $=.806$ ) indicating that the index is reliable.

\section{Control Variables}

Location, age, race, education, sex, and previous victimization are used as control variables. All of the control variables are operationalized using questions from the community survey. Participants were placed into their location by the surveyor with $0=$ Kettering, Ohio, 1=Knoxville, Tennessee, and 2=Broward County, Florida. Second, respondents were asked 
“how old were you on your last birthday?” Ages were simply coded as to how they responded. Respondents were asked about their race with the question "which of the following categories best describes your racial or ethnic heritage?” Answers for this question were recoded into $0=$ White, $1=$ Black, $2=$ Other. In order to measure education, respondents were asked "what is the highest grade or year of school you have completed?” Answers for education were recoded into the following categories: 0=less than high school, 1=high school or GED, 2=attended college, and $3=$ more than college. Participants were also asked their sex coded $0=$ male and $1=$ female.

For the control variable, previous victimization, the following questions were asked: “in the last year, has any of the following happened to you? Has your car been broken into, has your home been broken into, have you been beaten up or assaulted, and have you had someone take something from you by force or by threatening you with a weapon?” Participants could answer $0=$ no they had not been a victim of any of the crimes listed in the last year and 1=yes they had been the victim of at least one of the crimes listed in the past year.

\section{Methods}

Frequencies, correlations, and logistic regressions were completed to determine the relationship between an individual's fear of crime and their perceptions of police and to examine which measurement of fear of crime is a better predictor of perceptions of police. There are two main goals to this research: 1) to examine which measure of fear of crime is a better predictor when examining perceptions of police effectiveness and perceptions of community policing and 2) to examine the relationship between an individual's fear of crime and their perceptions of the police. Regressions will allow the comparison of the two fear of crime measures, specific versus general. Regressions will also allow the researcher to determine how much of an impact fear of crime and the control variables have on perceptions of the police 


\section{Sample Description}

Table 1 illustrates the demographic profile for each of the locations sampled: Knoxville, Tennessee, Kettering, Ohio, and Broward County, Florida. Kettering, Ohio is the smallest location with approximately 55,870 residents with 93\% of the population white and 3\% black (U.S. Census Bureau 2013). The U.S. Census Bureau (2013) reported that $21 \%$ of the population was younger than 18 years old while $18 \%$ are aged 65 years or older. The population was almost equally split between men and women with women representing 52\% of the city’s population (U.S. Census Bureau 2013). In Kettering, 62\% of the population owned their

\section{Table 1:}

Census Information, From 2013, For The Locations Kettering, Knoxville, and Broward County

\section{Location}

Kettering, Ohio Knoxville, Tennessee

Broward County, Florida

\begin{tabular}{|c|c|c|c|}
\hline Population & 55,870 & 183,270 & $1,838,844$ \\
\hline Female & $52.3 \%$ & $52.0 \%$ & $51.4 \%$ \\
\hline Male & $47.7 \%$ & $48.0 \%$ & $48.6 \%$ \\
\hline White & $92.6 \%$ & $76.1 \%$ & $40.8 \%$ \\
\hline Black & $3.3 \%$ & $17.1 \%$ & $28.5 \%$ \\
\hline Other Race & $4.1 \%$ & $6.8 \%$ & $30.7 \%$ \\
\hline $\begin{array}{l}\text { Household Median } \\
\text { Income }\end{array}$ & $\$ 49,522$ & $\$ 33,595$ & $\$ 51,251$ \\
\hline $\begin{array}{l}\text { Land Area in Square } \\
\text { Miles (From 2010) }\end{array}$ & 18.68 & 98.52 & $1,209.79$ \\
\hline $\begin{array}{l}\text { Size of Police } \\
\text { Department }\end{array}$ & $\begin{array}{r}83 \text { Sworn Officers } \\
26 \text { Civilian Employees }\end{array}$ & $\begin{array}{r}400 \text { Sworn Officers } \\
120 \text { Civilian } \\
\text { Employees }\end{array}$ & $\begin{array}{r}\text { 3,100 Certified } \\
\text { Deputies }\end{array}$ \\
\hline
\end{tabular}

own home, with the median household income being \$49,522 (U.S. Census Bureau 2013). The city of Kettering also has 83 sworn officers and 26 civilian employees (City of Kettering 2014). The Kettering police department is only one of a few its size to hold three concurrent awards of 
accreditation: law enforcement, jail, and communications (City of Kettering 2014). The officers of Kettering Ohio are highly encouraged to work with residents of the community while on and off duty (City of Kettering 2014).

Knoxville, Tennessee has approximately 138,270 residents with 76\% being white and 17\% being black (U.S. Census Bureau 2013). The age of residents in the city varied with, 13\% being 65 years or older and 19\% being 18 years or younger (U.S. Census Bureau 2013). Half of the resident population (50\%) owned their own homes, with a median household income of \$33,595 (U.S. Census Bureau 2013). Knoxville, Tennessee also has 400 sworn officers and 120 civilian personnel (Knoxville Police Department 2014). Knoxville is frequently cited in national surveys as a quality place to live, due to the reported low crime rate, and the interaction officers are encouraged to have with the community members (Knoxville Police Department 2014).

Finally, Broward County is the biggest with location with 1,838,844 residents, 41\% reporting they are white, 29\% reporting they are black, and 27\% reporting as Hispanic (U.S. Census Bureau 2013). Out of the residents, 66\% reported owning their own homes with a median income $\$ 51,251$ (U.S. Census Bureau 2013). There are 22\% of individuals under the age of 18 and 15\% of individuals over the age of 65 (U.S. Census Bureau 2013). In the county there are nearly 3,100 certified deputies which serve 16 specific areas of the County as well as 14 cities and towns that they have contracted with (Broward Sheriff's Office 2014).

\section{Statistical Analysis}

Table 2.1 illustrates the descriptive statistics of respondent characteristics for the dependent variables of police effectiveness and community policing. After deleting missing cases, the total sample size was 319. A majority of respondents (85.6\%) indicated they believe the police in their neighborhood are effective. The remaining $14 \%$ of respondents stated that the 
police are non-effective when dealing with problems that concern people in the neighborhood.

The second dependent variable, community policing's results are similar to police effectiveness.

Results indicate that 278 respondents (87.1\%) believe the police do a good job when working

together with residents and the remaining 41 respondents (12.9\%) indicating that police do a bad job working with residents of the neighborhood.

Table 2.1: Dependent Variables:

Descriptive Statistics of Respondent Characteristics, N = 319

Variable

$\underline{\mathbf{N}}$

Percent (\%)

How effective are police in dealing with problems that concern people in your neighborhood?

Non-Effective

46

14.4

Effective

273

85.6

\section{When working together with residents- police in your neighborhood do a?}

Bad Job 41

Good Job

278

Table 2.2 presents the descriptive statistics of respondent characteristics for the independent variable, fear of crime. Fear of crime was measured in two different ways. First it was measured by “general fear of crime.” General fear of crime was broken into three categories of not at all worried, somewhat worried, and very worried. Slightly over half of the respondents (53.9\%) indicated that they were not at all worried about crime. About $35 \%$ of respondents indicated that they were somewhat worried about crime, while, the remaining $11 \%$ of the respondents indicated that they were very worried about crime in their neighborhood. 
Table 2.2: Independent Variables:

Descriptive Statistics of Respondent Characteristics, N = 319

Variable

\section{General Fear of Crime}

Not at all Worried

Somewhat Worried

Very Worried
$\underline{\mathbf{N}}$

Percent (\%)

\section{Specific Fear of Crime Index}

Mean

172

112

Mode

8

Range

5-15

The second measure was specific fear of crime which was measured by an index created out of five variables that measure fear of specific types of victimization events. The index ranged from five to fifteen: a higher number represents a greater fear. The mean score for fear of crime was an eight, suggesting that individuals are somewhat worried about crime in the neighborhoods. Finally, the score that was most often seen was a five, indicating that the majority of individuals are not at all worried about crime in their neighborhood.

Table 2.3 illustrates the descriptive statistics of respondent characteristics for the control variables age, sex, race, education, previous victimization, and location. First, respondent's age ranged from 18 to 90 , with the mean age of 54 years old. There are more females than males in the sample with about $64 \%$ being female and $36 \%$ being male. A majority of respondents (80.3\%) indicated that they were white. About $14 \%$ responded that they were black and the remaining $6 \%$ indicated they were another race. Just over half of the respondents (54.1\%) responded that they attended college. The second largest group of respondents (31.1\%) has a high school diploma or GED. Only about 13\% of respondents have more than a college degree. 
Table 2.3: Control Variables:

Descriptive Statistics of Respondent Characteristics, N = 319

$\underline{\text { Variable }}$

Age

Mean

Range

Sex

Male

Female

Race

White

Black

Other

Highest level of education

Less than high school

High school or GED

Attended college

More than college

Previous Victimization

No

Yes

\section{Location}

Kettering, Ohio

107

108

104

54

18-90

117

202

256

44

19

6

99

172

41

254

64

Knoxville, Tennessee
Percent (\%)

36.7

63.3

80.3

13.8

6.0

31.1

54.1

12.9

79.9

20.1
33.5

33.9

32.6

Finally, about $2 \%$ of respondents have less than a high school diploma. Results show that a majority of respondents have not been victimized within the last year (79.9\%), and 20.1\% of respondents had been the victim of any type of crime, at least once, in the last year. Finally, respondents were almost equally split between the three locations of Kettering, Ohio (33.5\%), Knoxville, Tennessee (33.9\%), and Broward County, Florida (32.6\%).

Table 3.1 demonstrates the bivariate relationship between police effectiveness, community policing, previous victimization, respondent's sex, education, age, general fear of crime, and specific fear of crime. There is a very strong positive relationship between the 
Table 3.1:

Correlation Matrix of Police Effectiveness, Community Policing, Previous Victimization, Sex,

Education, Age, General Fear of Crime, and Specific Fear of Crime Index

\begin{tabular}{|c|c|c|c|c|c|c|c|c|}
\hline \multicolumn{9}{|c|}{$\mathrm{N}=319$} \\
\hline & $\begin{array}{c}\text { Police } \\
\text { Effectiveness }^{\mathrm{a}}\end{array}$ & $\begin{array}{l}\text { Community } \\
\text { Policing }^{\mathrm{b}}\end{array}$ & $\begin{array}{c}\text { Previous } \\
\text { Victimization }^{\mathrm{c}}\end{array}$ & $\begin{array}{l}\text { Respondent's } \\
\text { Sex }^{\mathrm{d}}\end{array}$ & $\begin{array}{l}\text { Respondent's } \\
\text { Education }\end{array}$ & $\begin{array}{l}\text { Respondent's } \\
\text { Age }\end{array}$ & $\begin{array}{l}\text { General } \\
\text { Fear of } \\
\text { Crime }^{\mathrm{e}}\end{array}$ & $\begin{array}{l}\text { Specific Fear of } \\
\text { Crime Index }\end{array}$ \\
\hline $\begin{array}{c}\text { Police } \\
\text { Effectiveness }^{\mathrm{a}}\end{array}$ & 1.00 & $.749 * *$ & $-.217^{* *}$ & .021 & .051 & .095 & $-.285^{* *}$ & $-.311^{* *}$ \\
\hline $\begin{array}{l}\text { Community } \\
\text { Policing }^{\mathrm{b}}\end{array}$ & & 1.00 & $-.205^{* *}$ & $.116^{*}$ & .086 & .103 & $-.215^{* *}$ & $-.177 * *$ \\
\hline $\begin{array}{c}\text { Previous } \\
\text { Victimization }^{\mathrm{c}}\end{array}$ & & & 1.00 & .058 & $-.116^{*}$ & $-.154^{* *}$ & $.223 * *$ & $.359 * *$ \\
\hline $\begin{array}{l}\text { Respondent’s } \\
\text { Sex }^{\mathrm{d}}\end{array}$ & & & & 1.00 & -.034 & .092 & $.217^{* *}$ & $.140 *$ \\
\hline $\begin{array}{l}\text { Respondent's } \\
\text { Education }\end{array}$ & & & & & 1.00 & -.106 & $-.141 *$ & $-.154 * *$ \\
\hline $\begin{array}{l}\text { Respondent’s } \\
\text { Age }\end{array}$ & & & & & & 1.00 & -.014 & -.012 \\
\hline $\begin{array}{c}\text { General Fear of } \\
\text { Crime }^{\mathrm{e}}\end{array}$ & & & & & & & 1.00 & $.637 * *$ \\
\hline $\begin{array}{l}\text { Specific Fear of } \\
\text { Crime Index }^{\mathrm{e}}\end{array}$ & & & & & & & & 1.00 \\
\hline $\begin{array}{r}\text { Note: }{ }^{*} \text { Correlati } \\
\text { ** Correlatio } \\
{ }^{\mathrm{a}} \text { Police E } \\
{ }^{\mathrm{b}} \text { Commu } \\
{ }^{\mathrm{c}} \text { Victimiz } \\
{ }^{\mathrm{d}} \text { Sex is as } \\
{ }^{\mathrm{e}} \text { Coded a }\end{array}$ & $\begin{array}{l}\text { is significant at t } \\
\text { s significant at th } \\
\text { ctiveness is as c } \\
\text { Policing is as c } \\
\text { on is as coded 0= } \\
\text { ded } 0=\text { "Male", } \\
=\text { ="Not Worried", }\end{array}$ & 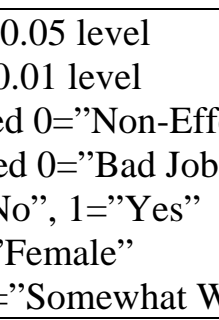 & $\begin{array}{l}\text { tive", 1=Effecti } \\
\text { 1=”Good Job” } \\
\text { rried”, 3=”Worr }\end{array}$ & & & & & \\
\hline
\end{tabular}


dependent variables police effectiveness and community policing $(r=.749 ; \mathrm{p}<.01)$. This indicates that as an individual's perceptions of police becomes more positive, they believe that their police are better involved with community policing. There is a relatively weak, but statistically significant, negative relationship between police effectiveness and whether or not a respondent has been previously victimized $(\mathrm{r}=-.217 ; \mathrm{p}<.01)$. The same relationship is shown between community policing and whether or not a respondent has been previously victimized ( $\mathrm{r}=-.205$; $\mathrm{p}<.01$ ). Both of these correlations suggest that individuals that have been previously victimized are going to have a more negative perception of police effectiveness and community policing.

Next, there is a statistically significant weak positive relationship between respondent's sex and community policing $(r=.116$; $\mathrm{p}<.05)$. This proposes that female respondents are more like to have a positive perception of community policing than male respondents. The differences in perception could be due to the type of interaction each of the sexes have with the police. Police might only interact with men when they are going to arrest them while they may interact with women to instill safety. This would in turn also affect how sex affects perceptions of police effectiveness. Just because a man has a negative interaction with the police does not mean he is not going to find them effective.

For general fear of crime, there is a moderate negative correlation with police effectiveness $(\mathrm{r}=-.285 ; \mathrm{p}<.01)$. A similar relationship is found between general fear of crime and community policing $(\mathrm{r}=-.215 ; \mathrm{p}<.01)$. These findings support what previous research has found, that as an individual's general fear of crime increases, their perceptions of police effectiveness and community policing decreases. There is a weak positive relationship between general fear of crime and respondent's sex $(\mathrm{r}=.217 ; \mathrm{p}<.01)$. This relationship suggests that women have a higher fear of crime than men; this also supports what previous research states. There is also a 
weak positive relationship between fear of crime and previous victimization $(\mathrm{r}=.217 ; \mathrm{p}<.01)$. This relationship suggests that respondent's that have been previously victimized have a higher fear of crime. Finally, there is a weak negative relationship between general fear of crime and respondent's education ( $\mathrm{r}=-.141 ; \mathrm{p}<.05)$. This indicates that as an individual's level of education increases, their fear of crime decreases.

There are several significant correlations for the variable specific fear of crime. First, there is a moderate negative relationship between specific fear of crime and police effectiveness. There is a weak negative relationship between specific fear of crime and community policing $(\mathrm{r}=-.177 ; \mathrm{p}<.01)$. Both of these correlations indicate that as an individual's fear of specific crimes increases, their perceptions of police effectiveness and perceptions of community policing decreases. There is a moderate positive relationship between specific fear of crime and previous victimization $(\mathrm{r}=.359 ; \mathrm{p}<.01)$. This implies that individuals that indicated they have been previously victimized are also going to report a higher specific fear of crime. There is a weak positive relationship with specific fear of crime and respondent's sex $(r=.140 ; \mathrm{p}<.05)$. This suggests again what previous research states, that women have a higher fear of crime than men. Next, respondent's education shows that there is a weak negative relationship with specific fear of crime $(\mathrm{r}=-.154 ; \mathrm{p}<.01)$. This shows that as an individual's level of education increases, their specific fear of crime decreases. Finally, there is a strong positive relationship between specific fear of crime and general fear of crime $(\mathrm{r}=.637 ; \mathrm{p}<.01)$. This shows that as an individual's general fear of crime increases, their fear of specific crimes also increases.

Table 3.2 shows the correlation matrix of the dummy coded variable race, with perceptions of police effectiveness and perceptions of community policing. There is a weak 


\section{Table 3.2:}

Correlation Matrix of Dummy Coded Race

With Perceptions of Police Effectiveness and Perceptions of Community Policing

Berceptions of
Community Policing
Perceptions of Police
Effectiveness
Note: * Correlation is significant at the 0.05 level
negative relationship between individuals that indicated they were black and perceptions of
community policing (r=-.118; p<0.05). This relationship suggests that black respondents have a
more negative perception of community policing. However, there is no statistically significant
relationship between black respondents and perceptions of police effectiveness. This could be
because of the type of interaction these respondents had with the police. If police are not
interacting with the respondents in a positive way they will report negative perceptions of
community policing but they might still view the police as being effective as preventing or
solving crime.

Table 3.3:

Correlation Matrix of Dummy Coded Location

With Perceptions of Police Effectiveness and Perceptions of Community Policing Kettering, Ohio Knoxville, Tennessee Broward County,

\begin{tabular}{cccc}
\hline & Kettering, Ohio & Knoxville, Tennessee & $\begin{array}{c}\text { Broward County, } \\
\text { Florida } \\
\text { Perceptions of }\end{array}$ \\
Community Policing & $.154^{* *}$ & $-.141^{*}$ & -.013 \\
& & & \\
$\begin{array}{c}\text { Perceptions of Police } \\
\text { Effectiveness }\end{array}$ & $.122^{*}$ & $-.121^{*}$ & .000 \\
\hline
\end{tabular}

Note: * Correlation is significant at the 0.05 level

**Correlation is significant at the 0.01 level

Table 3.3 illustrates the correlation matrix of the dummy coded variable location, with

perceptions of police effectiveness and perceptions of community policing. There is a weak 
positive relationship between the location of Kettering, Ohio and perceptions of community policing $(\mathrm{r}=.154, \mathrm{p}<0.02)$. There is a similar relationship between Kettering, Ohio and perceptions of police effectiveness $(r=.122 ; \mathrm{p}<0.05)$. Both of these relationships imply that individuals in Kettering are going to have a more positive perception of the police. Next, there is a weak negative correlation between Knoxville, Tennessee and perceptions of community policing $(\mathrm{r}=-.141 ; \mathrm{p}<0.05)$. There is also a weak negative correlation between Knoxville, Tennessee and perceptions of police effectiveness ( $\mathrm{r}=-.121 ; \mathrm{p}<0.05)$. Both of these correlations indicate that the residents of Knoxville, Tennessee will have a more negative perception of the police. These results demonstrate that resident location does matter. The difference could be because of the size of the community or the size of the police department. It could also be because of the types of policing each community uses. For example, the police in Kettering, Ohio could interact more with residents in a positive manner than the department in Knoxville, Tennessee. This finding is important to take into consideration when examining each individual location.

Table 4.1 shows the logistic regression results of respondent's perceptions of police effectiveness, accounting for individual's fear of crime and respondent individual characteristics. The dependent variable, perceptions of police effectiveness, is a binary variable (1=perceptions that police are effective). Model 1 of Table 4.1 illustrates that as an individual's general fear of crime increases they are $66 \%$ less likely to report a positive perception of police effectiveness $(\mathrm{p}<.01)$. Model 1 accounts for $12.7 \%$ of the variance in the dependent variable, police effectiveness.

In Model 2 of Table 4.1, the specific fear of crime index is introduced. When the specific fear of crime index is introduced, general fear of crime is no longer significant; however, the 
Table 4.1: Logistic Regression Results of Respondent's

Perceptions of Police Effectiveness Accounting for Fear of Crime and Respondent Individual Characteristics

\begin{tabular}{|c|c|c|c|c|}
\hline \multicolumn{5}{|c|}{ Dependent Variable: Perceptions of Police Effectiveness 1 = Effective, 0 = Non-Effective } \\
\hline $\begin{array}{l}\text { Regression Model } \\
\text { Independent Variables }\end{array}$ & $\begin{array}{c}\text { (Odds Ratios } \\
\text { Reported) } \\
(1)\end{array}$ & $\begin{array}{c}\text { (Odds Ratios } \\
\text { Reported) } \\
(2)\end{array}$ & $\begin{array}{c}\text { (Odds Ratios } \\
\text { Reported) } \\
\text { (3) }\end{array}$ & $\begin{array}{c}\text { (Odds Ratios } \\
\text { Reported) } \\
(4)\end{array}$ \\
\hline General Fear of Crime & $\begin{array}{l}.339 * * \\
(.228)\end{array}$ & $\begin{array}{c}.592 \\
(.294)\end{array}$ & $\begin{array}{c}.623 \\
(.302)\end{array}$ & $\begin{array}{c}.556 \\
(.324)\end{array}$ \\
\hline $\begin{array}{l}\text { Fear of Specific Crime } \\
\text { Index }\end{array}$ & & $\begin{array}{l}.783^{* *} \\
(.084) \\
\end{array}$ & $\begin{array}{l}.783^{* *} \\
(.086) \\
\end{array}$ & $\begin{array}{l}.787^{*} \\
(.095) \\
\end{array}$ \\
\hline \multicolumn{5}{|l|}{ Control Variables } \\
\hline Knoxville, Tennessee $^{\mathrm{a}}$ & & & $\begin{array}{c}.469 \\
(.444)\end{array}$ & $\begin{array}{l}.503 \\
(.460)\end{array}$ \\
\hline Broward County, Florida $^{a}$ & & & $\begin{array}{l}.791 \\
(.473)\end{array}$ & $\begin{array}{l}.895 \\
(.508)\end{array}$ \\
\hline High School or GED ${ }^{\mathrm{b}}$ & & & & $\begin{array}{c}1.580 \\
(1.117)\end{array}$ \\
\hline Attended College $\mathrm{b}^{\mathrm{b}}$ & & & & $\begin{array}{c}1.410 \\
(1.097)\end{array}$ \\
\hline More than College & & & & $\begin{array}{c}1.402 \\
(1.212)\end{array}$ \\
\hline $\operatorname{Sex}^{\mathrm{c}}$ & & & & $\begin{array}{l}1.681 \\
(.381)\end{array}$ \\
\hline Black $^{d}$ & & & & $\begin{array}{l}1.214 \\
(.537)\end{array}$ \\
\hline Other Race ${ }^{\mathrm{d}}$ & & & & $\begin{array}{l}4.215 \\
(.915)\end{array}$ \\
\hline Previous Victimization ${ }^{\mathrm{e}}$ & & & & $\begin{array}{l}.521 \\
(.398)\end{array}$ \\
\hline Age & & & & $\begin{array}{l}1.018 \\
(.012)\end{array}$ \\
\hline Constant & $\begin{array}{c}39.131^{* *} \\
(.470)\end{array}$ & $\begin{array}{c}125.549 * * \\
(.651)\end{array}$ & $\begin{array}{c}165.513^{* *} \\
(.690)\end{array}$ & $\begin{array}{c}39.580^{*} \\
(1.476)\end{array}$ \\
\hline Pseudo $\mathrm{R}^{2}$ & .127 & .172 & 189 & .242 \\
\hline \multicolumn{5}{|c|}{$\begin{array}{l}\text { Notes: *Relationship Significant at } 0.05 \text { level } \\
* * \text { Relationship significant at } 0.01 \text { level } \\
{ }^{\text {a }} \text { Reference group is Kettering, Ohio } \\
{ }^{\text {b }} \text { Reference group is less than high school } \\
{ }^{c} 0=\text { Male, } 1=\text { Female } \\
{ }^{\mathrm{d}} \text { Reference group is white } \\
{ }^{\mathrm{e}} 0=\text { No, } 1=\text { Yes }\end{array}$} \\
\hline
\end{tabular}


specific fear of crime index is significant $\left(\mathrm{p}^{<.01)}\right.$ indicating that specific fear of crimes is more influential then general fear of crime. This model shows that as individuals' fear of specific crimes increases, they are at a 22\% decreased odds of reporting a positive perception of police effectiveness. With the introduction of the specific fear of crime index, Model 2 accounts for a slight increase in the explained variance of the dependent variable (17.2\%).

Model 3 of Table 4.1 introduces the control variable of location. Even with the introduction of location, specific fear of crime does not change with individuals reporting a higher fear of crime having a 22\% decreased chance of reporting a positive perception of police effectiveness $\left(\mathrm{p}^{<.01)}\right.$. The control variable of location is not statistically significant in the logistic regression as it is in Table 3.3, indicating that there is a correlation between location and perceptions of police effectiveness but there is not a specific odds ratio. With this introduction however, the explained variance of police effectiveness does slightly increase to $18.9 \%$.

Finally, Model 4 of Table 4.1 introduces the remainder of the control variables: education, race, sex, previous victimization, and age. None of the control variables are significant in model 4 , although the specific fear of crime remains significant $(\mathrm{p}<.05)$. Model 4 of Table 4.1 shows that as an individual's fear of specific crimes increases, they are $21 \%$ less likely to report a positive perception of police effectiveness. Although much of the variance of police effectiveness is still unexplained, model 4 explains the most (24.2\%) due to the increased number of variables in the model.

Table 4.2 shows the logistic regression results of respondent's perceptions of community policing, accounting for individual's fear of crime and respondent individual characteristics. The 
Table 4.2: Logistic Regression Results of Respondent's

Perceptions of Community Policing Accounting for Fear of Crime and Respondent Individual Characteristics

\begin{tabular}{|c|c|c|c|c|}
\hline \multicolumn{5}{|c|}{ Dependent Variable: Perceptions of Community Policing 1 = Good Job, 0 = Bad Job } \\
\hline $\begin{array}{l}\text { Regression Model } \\
\text { Independent Variables }\end{array}$ & $\begin{array}{c}\text { (Odds Ratios } \\
\text { Reported) } \\
\text { (1) }\end{array}$ & $\begin{array}{c}\text { (Odds Ratios } \\
\text { Reported) } \\
\text { (2) }\end{array}$ & $\begin{array}{c}\text { (Odds Ratios } \\
\text { Reported) } \\
\text { (3) }\end{array}$ & $\begin{array}{c}\text { (Odds Ratios } \\
\text { Reported) } \\
\text { (4) }\end{array}$ \\
\hline General Fear of Crime & $\begin{array}{l}.410^{* *} \\
(.235)\end{array}$ & $\begin{array}{l}.475^{*} \\
(.310)\end{array}$ & $\begin{array}{l}.496^{*} \\
(.321)\end{array}$ & $\begin{array}{l}.399 * \\
(.360)\end{array}$ \\
\hline $\begin{array}{l}\text { Fear of Specific Crime } \\
\text { Index }\end{array}$ & & $\begin{array}{l}.940 \\
(.086)\end{array}$ & $\begin{array}{c}.953 \\
(.089)\end{array}$ & $\begin{array}{l}.977 \\
(.102)\end{array}$ \\
\hline \multicolumn{5}{|l|}{ Control Variables } \\
\hline Knoxville, Tennessee $^{a}$ & & & $\begin{array}{l}.293^{*} \\
(.496)\end{array}$ & $\begin{array}{l}.344^{*} \\
(.520)\end{array}$ \\
\hline Broward County, Florida $^{a}$ & & & $\begin{array}{l}.525 \\
(.527)\end{array}$ & $\begin{array}{l}.694 \\
(.576)\end{array}$ \\
\hline High School or GED ${ }^{b}$ & & & & $\begin{array}{c}1.605 \\
(1.147)\end{array}$ \\
\hline Attended College ${ }^{\mathrm{b}}$ & & & & $\begin{array}{c}2.788 \\
(1.132)\end{array}$ \\
\hline More than College ${ }^{b}$ & & & & $\begin{array}{c}1.871 \\
(1.241)\end{array}$ \\
\hline $\operatorname{Sex}^{\mathrm{c}}$ & & & & $\begin{array}{l}3.016^{* *} \\
(.405)\end{array}$ \\
\hline Black $^{\mathrm{d}}$ & & & & $\begin{array}{c}.880 \\
(.526)\end{array}$ \\
\hline Other Race $^{\mathrm{d}}$ & & & & $\begin{array}{c}6.940 \\
(1.165)\end{array}$ \\
\hline Previous Victimization ${ }^{\mathrm{e}}$ & & & & $\begin{array}{r}.398^{*} \\
(.423)\end{array}$ \\
\hline Age & & & & $\begin{array}{l}1.019 \\
(.013)\end{array}$ \\
\hline Constant & $\begin{array}{l}32.439 * * \\
\quad(.478)\end{array}$ & $\begin{array}{c}42.538^{* *} \\
(.612)\end{array}$ & $\begin{array}{c}72.233^{* *} \\
(.686)\end{array}$ & $\begin{array}{c}8.468 \\
(1.531)\end{array}$ \\
\hline Pseudo $\mathrm{R}^{2}$ & .084 & .087 & .127 & .243 \\
\hline $\begin{array}{c}\text { Notes: *Relationship Signi } \\
\text { ** Relationship sign } \\
{ }^{\text {a }} \text { Reference group i } \\
{ }^{\mathrm{b}} \text { Reference group i } \\
{ }^{\mathrm{c}} 0=\text { Male, } 1=\text { Femal } \\
{ }^{\mathrm{d}} \text { Reference group } \mathrm{i} \\
{ }^{\mathrm{e}} 0=\text { No, } 1=\text { Yes }\end{array}$ & $\begin{array}{l}\text { t at } 0.05 \text { level } \\
\text { tt at } 0.01 \text { level } \\
\text { tering, Ohio } \\
\text { than high scho } \\
\text { te }\end{array}$ & & & \\
\hline
\end{tabular}


dependent variable, perceptions of community policing, is a binary variable (1=perceptions that police are doing a good job of community policing). The logistic regressions, in Table 4.2, show that an individual's general fear of crime has a significant impact of their perceptions of community policing $(\mathrm{p}<.01)$. As an individual's fear of crime increases, both general and specific, the variable indicates that the individual perceives the police of doing a bad job of community policing. Model 1 of Table 4.2 shows that as an individual's fear of crime increases, they are 59\% less likely to report a positive perception of community policing. However, this model only accounts for about eight percent of the variance in the dependent variable.

In Model 2 of Table 4.2, the specific fear of crime index is introduced. Model 2 shows that general fear of crime is still significant when predicting perceptions of community policing $(\mathrm{p}<.05)$. Although similar to the first model, Model 2 shows that as an individual's fear of general crime increases, the likelihood that they will report that the police are doing a good job with community policing will decrease by $52.5 \%$, when the specific fear of crime index is introduced. The specific fear of crime index is not significant in any of the models it is introduced into, in Table 4.2, indicating that it is not a good predictor of perceptions of community policing. Like Model 1, Model 2 only accounts for eight percent of the variance in the dependent variable.

Model 3 presents the results of the introduction of the control variable location. General fear of crime maintains statistical significance in Model $3(\mathrm{p}<.05)$. This model shows that as an individual's general fear of crime increases, they are 50.4\% less likely to report a positive perception of community policing. Model 3 also demonstrates that the location of Knoxville, Tennessee is statistically significant $(\mathrm{p}<0.05)$. This relationship shows that respondents from Knoxville are $70 \%$ less likely to report a positive perception of community policing. Model 3 
accounts for $12.7 \%$ of the variance in community policing, indicating, that location is important because it helps explain the dependent variable.

Model 4, similar to the first three, shows that general fear of crime has a significant impact on an individual's perception of community policing $(\mathrm{p}<.05)$. Specifically, this model shows that as an individual's fear of crime increases, their odds of reporting a positive perception of community policing decreases by $60 \%$. Model 4 of Table 4.2 also introduces the control variables education, race, sex, previous victimization, and age. Model 4 of Table 4.2 indicates that the location of Knoxville, Tennessee maintains significance when the other control variables are introduced $(\mathrm{p}<.05)$. Model 4 of Table 4.2 illustrates that residents in Knoxville, Tennessee have a $65.6 \%$ decreased odds of reporting a positive perception of the police when compared to the base location of Kettering, Ohio. Model 4 of Table 4.2 shows that sex has a significant impact on perceptions of community policing $(\mathrm{p}<.01)$. These results show that women are $201 \%$ more likely than men to report a positive perception of community policing. The last variable in Model 4 of Table 4.2 to have a significant impact on perceptions of community policing is previous victimization $(\mathrm{p}<.05)$. This shows that respondents that have been previously victimized are about $60 \%$ less likely to report a positive perception of community policing. Almost 25\% of the variance is explained in Model 4. Model 4 is the best fitting Model in the Table 4.2 because it accounts for $24.3 \%$ of the variance in community policing.

\section{Discussion and Conclusion}

How an individual perceives the police is a very important topic to research because it impacts individuals in a multitude of different ways. Perceptions of police can impact how many police get hired, how much funding the departments obtain to pay their employees, who moves into the community, and how individuals interact with their fellow neighbors (Zhao, Lawton, and 
Longmire 2015). If individuals report a positive perception of the police, individuals and businesses that will have a positive impact on the community are more likely to move into that area. Also, the department is more likely to receive additional funding to hire more individuals and update their equipment. Even though a majority of individuals do not have direct interactions with the police, police effect every individual in society (Schafer et al. 2003; Thomas and Hyman 1977).

This research looked at how an individual's fear of crime, using a general fear measure and a specific fear measure, impact perceptions of the police. The results of the logistic regression in Table 4.1 of this study supported hypothesis one which stated that, the specific fear of crime measure will be a better predictor then the general fear of crime measure, when examining perceptions of police effectiveness. However, the results of the logistic regression in Table 4.2 of this study did not support the second hypothesis which stated that, the specific fear of crime measure will be a better predictor than the general fear of crime measure, when examining perceptions of community policing.

Due to the variation in the findings of this study, the results suggest that perceptions of community policing and perceptions of police effectiveness are measuring two different aspects of policing. Community policing could be interpreted as being broader then police effectiveness (Zhao et al. 2015). Also, just because a respondent thinks that police do a good job interacting with the community does not mean that they believe the police are effective at solving or preventing crime and vice-versa. Furthermore, the findings of this research suggest that a general fear of crime measurement is measuring how individuals overall perceive interactions with the police, while the specific fear of crime measurement is examining a more specific aspect of police, such as, do police solve and/or prevent crimes (Baumer 1985; Covington and Taylor 
1991; Wyant 2008). Therefore, the general fear of crime measure would be a better predictor at measuring a general measurement of perceptions of police; while a specific fear of crime measure would be a better predictor of a specific measure of perceptions of police (Wyant 2008). Additionally, this could be why both the general and specific measure had a statistically significant relationship with both measures of perceptions of the police in Table 3.1. There is a correlation between both independent and dependent variables but the more specific relationship that comes out in Tables 4.1 and 4.2 tell a more accurate story. Thus, it is important to determine what exactly the research is aiming to answer, in order to determine which type of measurement is the most appropriate to use.

Finally, the third hypothesis, as an individual's fear of crime increases, their perceptions of police become more negative was supported. As shown in the logistic regression results in Tables 4.1 and 4.2 all fear of crime measures indicate that as an individual's fear of crime increases, they are less likely to view police as effective and doing a good job with community policing. Even though a different measure of perceptions of police was used, this finding supports what Weitzer and Tuch (2005) and Kort-Butler and Sittner Hartshorn (2011) found to be statistically significant. Although, Skogan (2009) did not find results to be statistically significant, his findings did suggest that as an individual's fear of crime increases, their perceptions of the police will become more negative.

The findings that support the third hypothesis suggest that even though the better measurement depends on what is being measured, the relationship between fear of crime and perceptions of police does not change. Whether a general or specific fear of crime measurement is used and whether it is being compared to perceptions of community policing or perceptions of 
police effectiveness, results found that as an individual's fear of crime increases, their perceptions of the police become more negative.

Only three control variables are statistically significant in Table 4.2 which examined perceptions of community policing. The control variables sex and previous victimization are statistically significant when examining perceptions of community policing but not when examining perceptions of police effectiveness $(\mathrm{p}<.05)$. The data suggest that there is a difference between how individuals perceive interactions with the police and their perceived police effectiveness. Individuals that have been previously victimized are more likely to have a higher fear of crime and feel more vulnerable to crime (Rader et al. 2012; Scarborough et al. 2010; Schafer et al. 2006; Zhao et al. 2015). For instance, an individual could perceive the police to be effective in their communities because they feel safe from crime or feel they will not be victimized again but that does not mean they like interacting with the police. They could view the police as unfriendly to work with or hard to approach. Therefore, this data suggest that just because a police department might be considered effective does not mean individuals in the community believe the police to be doing a good job with community policing. This point goes back to what previous research has said, when an individual has an interaction with the police, that interaction has a heavy influence on their perceptions of police (Maxson et al. 2003; Schafer et al. 2003; Thomas and Hyman 1977).

Another reason for the significance of the sex on perceptions of community policing could stem from the vulnerability model. Research shows that, overall, women have a higher fear of crime than men do (Rader et al. 2012; Scarborough et al. 2010; Schafer et al. 2006). However, women are actually less likely to be a victim of every type of crime, except for sexual assaults (Scarborough et al. 2010). By women having a high fear of crime but not actually 
falling victim to a majority of crimes, they could be having more positive interactions with police then men are. This all contributes to an individual's perceptions.

For the variable location, only Knoxville, Tennessee was statistically significant $(\mathrm{p}<.05)$. Additionally for location, the results in Table 3.3 show a significant relationship between location and both dependent variables. The difference between the bivariate correlations and the regression models indicates that there is a correlation between location and the dependent variables when they are alone. However, once additional variables are introduced, location looses significance except for Knoxville, Tennessee in Table 4.2. An explanation for the data outcome might be because of the type of policing Knoxville has, compared to the other locations. Additionally, the results could be because of the size of the location (Zhao et al. 2015). Each location being examined is a different size.

Finally, a third reason for the significance of Knoxville could be due to the type of disorder individuals perceive in their neighborhood. As Skogan (1986) stated, individuals can become desensitized to disorder which would in turn impact their fear of crime and perceptions of the police. Furthermore, each location in the study has a different "stable" in their neighborhood, which greatly impacts an individual's perceptions of the police (Skogan 1986). Finally, although there is no empirical evidence to support these perceptions, there is a stereotype that surrounds the south (Hawley and Messner 1989). Southerners are tended to be viewed as more violent or more likely to commit a crime, which in turns mean police tend to police them harder and they are sentenced to more harsh punishments (Hawley and Messner 1989). All of these reasons can all contribute to why Knoxville was statistically significant for perceptions of community policing compared to the other locations. The size and interaction of the police and 
the community is going to be based more on the type of policing, size of the community, and size of the department.

The remainder of the control variables, age, education, and race were not statistically significant, though previous research suggests they should be. This could be due to the sample of respondents that was collected. The results in Table 2.1 and 2.2 showed that a majority of the respondents reported a low fear of crime and positive perceptions of the police, meaning they were satisfied with the police. Therefore, there was not a lot of variation in the answers of respondents. This could have had an impact on the analysis results. If this study contained a greater variety of answers the control variables might have become statistically significant.

\section{Limitations and Future Research}

There were some limitations to this study. For instance, this was a cross-sectional study. Therefore, it did not allow for the researchers to see how an individual's fear of crime might have changed over time. Research shows that fear of crime is impacted by everything an individual experiences, but a cross-sectional study does not give opportunity to examine the change in the relationship. Although this study examined respondents from three different geographical locations, it would be beneficial for future researchers to examine a different part of the country. Additionally, there is not a very large sample size in this study which could account for the lack of statistically significant findings. The three locations were combined in the logistic regression in efforts to produce a stronger sample. Finally, since there was a difference between which measurement is the better predictor of perceptions of police, additional research needs to be done on this topic.

This research was beneficial due to the fact that it examined a topic that has been overlooked in previous research. Furthermore, this research was valuable because in the limited 
previous research there has been conflicting findings. Although a few researchers have brought to light that a new measure of fear of crime needs to be used, none have done a comparison between the two measures to determine which is a better predictor. Therefore, this study contributes in many ways to research and fills many gaps.

The question "how safe do you feel walking alone at night in your neighborhood?” was the first measure used in the 1980s and it is what researchers continue today to use (Baumer 1985). However, some researchers state that the general fear of crime measure is somewhat cloudy and it is argued that it does not fully capture an individual's fear of crime. Since 2000, researchers have started to ask individuals about their fear of specific types of crime (Kort-Butler and Sittner Hartshorn 2011; Skogan 2009). By asking individuals a more specific fear of crime question, respondents are less likely to interpret the questions in different ways, allowing the researcher to obtain more reliable and accurate information.

In conclusion, this study both supports and refutes what previous researchers argue about the different measurements (Ferraro and LaGrange 1987; Kort-Butler and Sittner Hartshorn 2011; Skogan 2009; Weitzer and Tuch 2005). These findings would suggest that the appropriate way to measure fear of crime, depends on what fear of crime is being compared to. When examining perceptions of police effectiveness it appears that an individual's fear of victimization for specific crimes (specific fear of crime measure) is more predictive. However, when examining perceptions of community policing, or how well police work with members of the community, a general fear of crime measure is a better predictor. This would indicate that the more specific the dependent variable being measured, here perceptions of police, determines how specific the fear of crime variable should be measured. Additionally, the results show that no 
matter which fear of crime measure being used, as an individual's fear of crime increases, their perceptions of the police become more negative. 


\section{References}

Baumer, Terry L. 1985. “Testing a General Model of Fear of Crime.” Journal of Research on Crime and Delinquency 22:239-256.

Benedict, Reed., Ben Brown, and Douglas J. Bower. 2000. "Perceptions of the Police and Fear of Crime in a Rural Setting: Utility of a Geographically Focused Survey for Police Services, Planning, and Assessment.” Criminal Justice Policy Review 11(4):275-298.

Broward County Sheriff's Office. 2014. Retrieved December 14, 2014.

(http://www.sheriff.org/about_bso/dle/districts/).

Chadee, Derek. And Nikita K. Ng Ying. 2013. "Predictors of Fear of Crime: General Fear versus Perceived Risk.” Journal of Applied Social Psychology 43(1):1896-1904.

City of Kettering. 2014. Retrieved December 14, 2014.

(http://www.ketteringoh.org/departments/police/).

Covington, Jeanette and Ralph B. Taylor. 1991. “Fear of Crime in Urban Residential

Neighborhoods: Implications of Between-and-Within Neighborhood Sources for Current Models.” The Sociological Quarterly 32(1):231-249.

Ferraro, Kenneth. and Randy L. LaGrange. 1987. “The Measurement of Fear of Crime.” Sociological Inquiry 57(1):70-101.

Glassner, Barry. 2009. “The Culture of Fear Why Americans are Afraid of the Wrong Things: Crime Drugs, Minorities, Teen Moms, Killer Kids, Mutant Microbes, Plane Crashes, Road Rage, \& So Much More.” New York, NY: Basic Books.

Hawley, F. Frederick. And Steven F. Messner. 1989. “The Sourthern Violence Construct: A Review of Arguments, Evidence, and the Normative Context.” Justice Quarterly 6(4):481-511. 
Kelling, George L. Tony Pate, Duane Dieckman, and Charles E. Brown. 1974. “The Kansas City Preventative Patrol Experiment: A Summary Report.” Police Foundation 1-42.

Knoxville Police Department. 2014. Retrieved December 14, 2014. (http://www.cityofknoxville.org/kpd/mission.asp).

Kort-Butler, Lisa A. and Kelley J. Sittner Hartshorn. 2011. "Watching the Detectives: Crime Programming, Fear of Crime, and Attitudes about the Criminal Justice System.” The Sociological Inquiry 52(1):36-55.

LaGrange, Randy L., Kenneth F. Ferraro, and Michael Supancic. 1992. "Perceived Risk and Fear of Crime: Role of Social and Physical Incivilities.” Journal of Research in Crime and Delinquency 29(3):311-334.

Rader, Nicole E., Jeralynn S. Cossman, and Jeremy R. Porter. 2012. "Fear of Crime and Vulnerability: Using a National Sample of Americans to Examine Two Competing Paradigms.” Journal of Criminal Justice 40(1):134-141.

Scarborough, Brittney K., Toya Z. Like-Haislip, Kenneth J. Novak, Wayne L. Lucas, and Leanne F. Alarid. 2010. “Assessing the Relationship between Individual Characteristics, Neighborhood Context, and Fear of Crime.” Journal of Criminal Justice 38(1):819-826.

Schafer, Joseph A., Beth M. Huebner, and Timothy S. Bynum. 2003. “Citizen Perceptions of Police Services: Race, Neighborhood Context, and Community Policing.” Police Quarterly 6(4):440-468.

Schafer, Joseph A., Beth M. Huebner, and Timothy S. Bynum. 2006. "Fear of Crime and Criminal Victimization: Gender-Based Contrasts.” Journal of Criminal Justice 34(1):285-301. 
Skogan, Wesley G. 2009. “Concern about Crime and Confidence in the Police: Reassurance or Accountability?” Police Quarterly 12(3):301-318.

Skogan. Wesley G. 1986. “Fear of Crime and Neighborhood Change.” Journal of Crime and Justice 8(1):203-229.

Thomas, Charles W. and Jeffrey M. Hyman. 1977. "Perceptions of Crime, Fear of Victimization, and Public Perceptions of Police Performance.” Journal of Police Science and Administration 5(3):305-317.

U.S. Bureau of Census. 2013. Broward County, Florida People Quick Facts.

U.S Bureau of Census. 2013. Kettering, Ohio People Quick Facts.

U.S. Bureau of Census. 2013. Knoxville, Tennessee People Quick Facts.

Warr, Mark. And Mark Stafford. 1983. "Fear of Victimization: A Look at the Proximate Causes.” Social Forces 61(4):1033-1043.

Weitzer, Ronald. And Steven A. Tuch. 2005. "Determinants of Public Satisfaction with the Police.” Police Quarterly 8(3):279-297.

Wilson, James Q. and George L. Kelling. “Broken Windows.” Atlantic Monthly 249(3):29-38.

Wyant, Brian R. 2008. "Multilevel Impacts of Perceived Incivilities and Perceptions of Crime Risk on Fear of Crime: Isolating Endogenous Impacts.” Journal of Research in Crime and Delinquency 45(1):39-64.

Zhao, Jihong Solomon., Brian Lawton, and Dennis Longmire. 2015. “An Examination of the Micro-Level Crime-Fear of Crime Link.” Journal of Research in Crime and Delinquency 61(1):19-44. 